\title{
Thick skins in place, thick skins out of place: re- placing homeless bodies in spaces of care
}

\section{Panos Bourlessas}

To cite this article: Panos Bourlessas (2020): Thick skins in place, thick skins out of place: re-placing homeless bodies in spaces of care, Social \& Cultural Geography, DOI: 10.1080/14649365.2020.1837214

To link to this article: https://doi.org/10.1080/14649365.2020.1837214

\section{Published online: 17 Oct 2020.}

Submit your article to this journal

Џll Article views: 15

Q View related articles $\asymp$

View Crossmark data $₫$ 


\title{
Thick skins in place, thick skins out of place: re-placing homeless bodies in spaces of care
}

\author{
Panos Bourlessas \\ Department of Cultures, Politics and Society, University of Turin, Torino, TO, Italy
}

\begin{abstract}
The 'homeless body' has been largely constructed in scholarship as a 'discursive body' while it has been inadequately grounded in empirical space. Drawing from ethnographic research, this article attempts a twofold, gradual re-placement: a conceptual replacement of the 'discursive homeless body' as material bodies, which shape homeless subjectivities; and a spatial re-placement of these bodies in Athens' formal spaces of care, where homeless subjects respond to the provided care through a personal body work. The replacement is conceptualized through 'stigma dialectic', namely, the continuous embodiment and emplacement of the homeless stigma within these spaces. There, the stigmatized as 'dirty' homeless subjects achieve a geographical-social ordering as visceral practices of cleanliness make homeless bodies 'in place', closer to the nonstigmatized staff and volunteers. At the same time though, and while 'in place', homeless subjects try to make their bodies 'out of place', away from other, stigmatized homeless bodies. Informed by literatures on geographies of care, visceral geographies, and by performative approaches to homeless geographies, the article suggests that the personal body work might have significant implications for a neoliberalizing ethic of care, the spaces it structures and is enabled through, and the homeless subjectivities it structures, especially in times of welfare restructuring.
\end{abstract}

\section{Pieles gruesas en su lugar, pieles gruesas fuera de lugar: reubicación de cuerpos sin hogar en espacios de cuidado}

\section{RESUMEN}

El 'cuerpo sin hogar' se ha construido en gran medida en los estudios académicos como un 'cuerpo discursivo', mientras que no se ha basado adecuadamente en el espacio empírico. Partiendo de la investigación etnográfica, este artículo intenta una reubicación gradual y doble: una sustitución conceptual del 'cuerpo discursivo sin hogar' como cuerpos materiales, que dan forma a las subjetividades sin hogar; y una reubicación espacial de estos cuerpos en los espacios formales de cuidado de Atenas, donde los

\section{ARTICLE HISTORY}

Received 27 March 2019

Accepted 11 September 2020

\section{KEYWORDS}

Homelessness; body; ethnography; Athens; (spaces of) care; stigma dialectic

\section{PALABRAS CLAVE}

indigencia; cuerpo; etnografía; Atenas; (espacios de) cuidado; dialéctica del estigma

\section{MOTS-CLEFS}

sans-abrisme; corps; ethnographie; Athènes; (espaces de) care; dialectique de la stigmatisation

CONTACT Panos Bourlessas, panagiotis.bourlessas@unito.it Department of Cultures, Politics and Society, University of Turin, Torino, TO 10153, Italy

This article has been republished with minor changes. These changes do not impact the academic content of the article. 
sujetos sin hogar responden al cuidado brindado a través de un trabajo corporal personal. La reubicación se conceptualiza a través de la 'dialéctica del estigma', es decir, la encarnación y el emplazamiento continuos del estigma sin hogar dentro de estos espacios. Allí, los estigmatizados como sujetos sin hogar 'sucios' logran un ordenamiento geográfico-social a medida que las prácticas viscerales de limpieza hacen que los cuerpos de los sin hogar 'estén en su lugar', más cerca del personal y los voluntarios no estigmatizados. Sin embargo, al mismo tiempo, y mientras están 'en su lugar', los sujetos sin hogar tratan de hacer que sus cuerpos 'estén fuera de lugar', lejos de otros cuerpos sin hogar estigmatizados. Basado en la literatura sobre geografías del cuidado, geografías viscerales y enfoques performativos de las geografías sin hogar, el artículo sugiere que el trabajo corporal personal podría tener implicaciones significativas para una ética neoliberalizadora del cuidado, los espacios que estructura y a través de los cuales se habilita, y las subjetividades sin hogar que estructura, especialmente en tiempos de reestructuración del bienestar.

\section{Peaux dures en place, peaux dures déplacées: le re- placement des corps sans-abri dans les espaces de care}

\section{RÉSUMÉ}

Le "corps sans-abri » a été essentiellement construit dans les recherches comme un "corps discursif » bien qu'il ait été fondé de manière inadéquate dans l'espace empirique. En faisant appel à la recherche ethnographique, cet article tente un re-placement double et progressif: un re-placement conceptuel du « corps sansabri discursif » comme entités matérielles, qui forment les subjectivités du sans-abrisme; et un re-placement spatial de ces corps dans des espaces formels de care, à Athènes, où les sansabris réagissent aux soins offerts à travers un travail corporel personnel. Le re-placement est conceptualisé au travers d'une "dialectique de la stigmatisation», à savoir, l'incarnation et l'emplacement continuels de la stigmatisation des sans-abris au sein de ces espaces. Là, les sans-abris stigmatisés comme "sales» achèvent un ordre géographique et social, car les pratiques viscérales de propreté mettent leurs corps "en place", plus près du personnel et des volontaires non stigmatisés. Cependant, en même temps et bien qu' "en place ", les sans-abris essayent de rendre leur corps " déplacés», loin des autres corps stigmatisés sans-abris. Guidé par les études sur la géographie du care, la géographie viscérale et les approches performatives de la géographie des sans-abris, l'article suggère que le travail corporel personnel pourrait avoir d'importantes répercussions pour une éthique de néo-libéralisation du care, les espaces qu'il structure et dans lesquels on l'active et les subjectivités du sans-abrisme qu'il articule, en particulier pendant des périodes de réorganisation des services sociaux. 


\section{Introduction}

Our meeting point was the cafeteria of the Greek National Theatre; cozy, affordable and never crowded, ideal for a 'good' interview. On entering, Élsa ${ }^{1}$ stopped for a second; and so did I - until that moment our bodies had been synchronized. 'My hands look ugly! I don't have a nail clipper to cut my nails', she said looking at her hands. I myself remained silent. She did not feel comfortable here, she confessed, not suited to the place. I was expecting that especially Élsa would have appreciated the atmosphere, having worked for years in theatres. In fact, later on she would tell that the place did feel familiar - what a relief! Nevertheless, my plan had, at least momentarily, failed; Élsa's body felt inappropriate. Surrounded by the cafeteria's well-curated aesthetics and middle-class patrons, her long and slightly blackened nails rendered her entire body 'out of place'. It took us a joke and a few seconds before we finally sat at the table - although our bodies would then be less synchronized. Around the same table, her body and my body were now distant.

Élsa is a Greek woman in her early fifties. She became homeless after splitting with her ex-husband and after experiencing psychological issues. None of her acquaintances responded to her need for accommodation. Having no alternatives, Élsa found herself in Athens' spaces of care from the very first day; for almost a year now, she rests her body at the only night shelter for homeless people in central city and washes her body at a near-by day centre when water supply problems occur at the shelter. Through Élsa's and others' bodies, in this paper I seek to re-place 'the homeless body'. If the visceral requires situated and contextual approaches (Hayes-Conroy \& Hayes-Conroy, 2010), then I seek so by empirically placing the homeless body specifically (what the hyphen of 're-place' stresses) in spatialities wherein homeless bodies are largely made in western societies, namely spatialities of care, and in a context of fiscal austerity and welfare restructuring, namely that of the Greek capital.

The article departs from a critique of 'the discursive homeless body' suggesting a dual and gradual - first conceptual, then spatial - re-placement. First, the singular 'discursive homeless body' is replaced as subjective material bodies through which homeless selves are shaped; then, these bodies are re-placed in Athens' spaces of care. By situating homeless bodies right there, a multifold contribution is achieved. Precisely, research on homelessness and spaces of care (Cloke et al., 2010; Conradson, 2003; Johnsen et al., 2005) has not addressed adequately the role of bodies in the reciprocal making of homeless subjectivities and spatialities whilst, conversely, spaces of care for homeless people are absent in recent reviews on geographies of care (Bartos, 2019; Power \& Hall, 2018). Moreover, given the underrepresentation of care-recipients in research (Atkinson et al., 2011; Hanrahan, 2018; Milligan \& Wiles, 2010; Wiles, 2011), the paper attends to Tronto's fourth moral moment of care, namely 'responsiveness' (Tronto, 1993, p. 134). Emphasizing the role of stigma in the discourses, practices and spatialities of this responsiveness, it attends to how the 'objects (sic) of care' respond to care (ibid.), and to how body-subject relations are shaped, enriching simultaneously emergent relational and encounter-centered approaches to voluntary spaces (DeVerteuil et al., 2019). Overall, the practical-material making of homeless bodies through personal body work does not only unveil empirically the role of the visceral in the complexities and ambivalences of care (Bartos, 2018, 2019; Cox, 2010; 
McEwan \& Goodman, 2010), but allows for broader reflections on an emerging, neoliberalizing ethic of care, the spaces and bodies these ethics structure and are enabled through, and the homeless subjectivities that it shapes in contexts of welfare restructuring.

The article draws from seven months of ethnographic fieldwork conducted at a night shelter, a day centre and two hostels for homeless people in central Athens between 2016 and 2017. The context and practicalities of the research have been discussed elsewhere (Bourlessas, 2019). The overrepresentation of male research participants (especially Greek nationals) reflects their overrepresentation in the researched spaces. I depart from a critical literature review on what will be called as the 'discursive homeless body' and bridge to approaches sensitive to bodily materialities, useful for the attempted replacement. I then clarify the ways in which this article stretches the boundaries of care, precisely in relation to Athens' welfare restructuring and the personal body work (of the subjects on their own individual bodies), characteristic of the city's formal spaces of care, and draw the conceptual framework of 'stigma dialectic' for the empirical analysis. Following, I exemplify how becoming homeless involves the parallel material becoming of a 'new body' for the subjects. Afterwards, I situate these material, stigmatized as 'dirty', bodies in Athens' spaces of care, where they are viscerally made 'in place' through practices of cleanliness; like this, the personal body work performs a desired geographical and social ordering for homeless subjects. In the final empirical section, I illustrate how, paradoxically in their in-placement, homeless subjects try nevertheless to make their bodies 'out of place' in order to stay distant from, and untouched by, other, residual, stigmatized homeless bodies located in the very same spaces. Concluding, I reflect on this in-placeness/out-of-placeness paradoxical tension to suggest that the personal body work might facilitate the incorporation of a neoliberalizing ethic of care that shapes homeless care-recipients as active, responsible and, above all, resilient subjectivities in an increasingly insecure social environment and conditional care provision for vulnerable people.

\section{Replacing the 'discursive homeless body'}

In her seminal article, Kawash (1998) constructs perhaps the only explicit theoretical account on the homeless body. According to her, the 'homeless' and the 'public' become two separate entities through the homeless body, the latter being opposed to a 'phantom public'. Visible and surrounded by the few remaining possessions, along with specific activities carried out in public, the homeless body develops its relationship with space through a twofold process: through placelessness, due to continuous movement; and through containment, due to the dependence on the services that cater to bodily needs. More recent studies seem to keep up with and extend this theoretical construct of the homeless body as the 'mainstream' society's Other, precisely being that which carries 'dirt' within and for society (Hodgetts et al., 2012; Toft, 2014; Watson, 2000; Wright, 2000). It is through the notion of 'dirt', and of residues generally (Sibley, 1995), that the homeless body separates symbolically homeless people from the rest of society (also A. F. Smith, 2014); the latter reacts in order to restore a desired 'order' that the homeless body threatens through its dirt. In the spectacularized, aestheticized and highly consumerist modern societies, visible homeless bodies become thus the symbolic 'stains and blights on the city space' (Gerrard \& Farrugia, 2014, p. 3). And through urban encounters with 
'consuming bodies', the 'dirty' presence of the homeless body becomes part of everyday visual discourses, wherein this body is made and reproduced as 'social pollutant' (Urry, 1995 , p. 188), relating simultaneously to the aesthetic politics of consumer capitalism overall (Gerrard \& Farrugia, 2014; also Hillis, 2008).

These approaches point towards significant and, for this article, pivotal possibilities for critical engagements with the homeless body, precisely because of their emphasis on 'dirt'. However, I contend, they largely construct the homeless body as a 'discursive body' (Massumi, 2002, p. 2) - the 'discursive homeless body': immaterial, singular, inadequately grounded in empirical space, disconnected from the subjectivities it embodies. And so is constructed the 'dirt' it carries for society; as discursive, abstracted, ineffective, unbodied. In this sense, the twofold danger that the discursive homeless body is pregnant with in its abstract singularity, is first to reproduce a 'universal homeless subject' (DeVerteuil et al., 2009, p. 650), and second, by focusing exclusively on public space, to mute less visible spatialities where this 'dirt' is experienced. To combat this danger, I bridge to the limited studies that highlight material aspects and construct homeless bodies as active sites through which different homeless selves are physically enacted, performed and negotiated (Parsell, 2011), so as to place them afterwards in spaces of care. For lacking shelter is 'a fully embodied [...] experience which is mediated by spatial and intersubjective processes' (Farrugia, 2011, p. 24, emphasis added).

Analyzing the various materializations of care Lancione $(2014,2016))$ mobilizes assemblage theory to highlight the affective aspects of sheltering, feeding and encountering other bodies, whereas, regarding the Athenian context, Bourlessas (2018) illustrates how self-responsibilisation discourses concretize in forms of mobility experienced bodily. Other studies center more explicitly on the homeless bodies as material sites for the homeless condition and agency. In Daya and Wilkins (2012) cultural geographic account, the body, interrelating to other spatialities, is the subjective affective space where senses of home and belonging are negotiated and achieved in practical and less rational ways. And Higate (2000), focusing on physicality, illustrates how crucial the body is for the physical making of masculine homeless subjectivities: physically tested in difficult conditions, it continues previous embodied experiences while interacting actively with the food it ingests.

Departing from the above critique, I engage with this latter research niche, echoing too performative takes on homeless geographies (Cloke et al., 2008; Jolley, 2020), in order to re-place the discursive homeless body - to expose the empirical bodies within the discursive body. For this re-placement, I consider the body as "the very "stuff" of [homeless] subjectivity' (Grosz, 1994, p. ix), and then bring to centre stage some 'spatial relationships [that] come together to make bodies and places, through the body and through places, [...] in places, through the body' (Nast \& Pile, 1998, p. 4). These places are Athens' spaces of care, wherein homeless bodies are located and cared for through corporeal practices. Arguing against any reification of 'the [singular] body' (Turner, 2008), in their 'weighty materiality' the homeless bodies that follow are in a constant 'state of becoming with places' (Longhurst, 2001, p. 5). The following section specifies the approach to care, presents the relevant contextual particularities (namely welfare restructuring, formal spaces of care, and personal body work), and suggests a conceptual framework based on the idea of stigma. The latter, inspired by 
the experiences of research participants, proves necessary in order to materialize the 'dirt' homeless bodies are discursively associated with, and to unveil its material effects through a cultural-geographic approach that goes beyond the visible public space. For dirt is lived as much as it is spaced.

\section{Stretching the boundaries of care in Athens}

Geographers have recently called for stretching the boundaries of care towards terrains other than that of family and individual care (Bartos, 2019), and for considering austerity and the thinning out of welfare state in the multiscalar care restructuring (Cox, 2013; Power \& Hall, 2018). Focusing on spaces of care for homeless people in a context of care restructuring, this article stretches these boundaries in three ways. First, conceiving of care as practiced (Atkinson et al., 2011; Bondi, 2003; Tronto, 1993), it centres on bodies through respective visceral practices in spaces of care (see Dyck et al., 2005; Vaittinen, 2015). Second, attending to the various scales through which care is enacted (Atkinson, 2011; Milligan, 2003; Power \& Hall, 2018), it intersects the scales of bodies and of care spatialities, stressing that 'Embodied caring practices must be analyzed as multisited [and] multiscalar' (Lawson, 2007, p. 6). And third, considering the (inter-)subjective aspects of situated caring relations (Bondi, 2003; Hanrahan, 2018), it brings to the fore empirically how the making of homeless bodies inside spaces of care involves too the making of homeless subjectivities.

\section{Welfare neoliberalization, formal spaces of care, and personal body work}

In Athens, the sovereign debt-crisis has resulted in an unprecedented change of the city's human landscape. Alongside the preexisting urban poor, the city centre has recently experienced the emergence of a population that once belonged to the middle strata but is now dramatically impoverished; the 'nouveau poor' (Kaika, 2012). The emergence of this new poor - especially of the so-called 'new homeless' (Theodorikakou et al., 2013) - has been so socially and politically contested that it led in 2012 to the first constitutional recognition of people without shelter as a vulnerable group in Greece. At the same time, an already residual welfare state (Zambarloukou, 2015) is being restructured through austerity policies, with the engagement of non-governmental and private institutions (Chorianopoulos \& Tselepi, 2017). The spatial result of this restructuring is an emerging, 'contested landscape' composed of spaces such as shelters, hostels, day centres, soup kitchens, social pharmacies and others (Arapoglou \& Gounis, 2017). Two specific characteristics that render this landscape contested are relevant here.

First, the landscape is shaped by competing strategies of dealing with poverty and homelessness, namely, both non-formalized and formalized strategies (Arapoglou \& Gounis, 2017). The former crystalize in grassroot initiatives of neo-communitarian social support; the latter in spaces of care managed by public and non-governmental institutions. This paper focuses exclusively on some of these latter institutional spaces of care (see also Bourlessas, 2019) so as to reveal some of the formal (spatial) ways in which 'mainstream' society cares for, and manages, its own vulnerable, new 'Others'. Second, the formation of this landscape is due to a post-welfare restructuring 'shaped by both neoliberal mentality and neo-communitarian practices' (Arapoglou \& Gounis, 2017, pp. 2-3). Stemming from formal spaces of care within the overall landscape as stated above, 
the evidence of this paper should be thus framed in terms of the shifting mentality that neoliberalizes the Greek welfare state, producing its very spaces.

Within the last decade, an emergency model was implemented, which marked the 'rolling-with neoliberalisation [of welfare provision], confining anti-poverty and social inclusion policies to managing the poor' (Arapoglou \& Gounis, 2017, p. 90). Instead of structural solutions then, the overall neoliberalization, with strong workfarist directions, shaped specific moralities of sorting, and dealing with, the poor in the emerging landscape. Regarding specifically the spaces of care investigated for this article, two elements one discursive, one practical - of welfare neoliberalization should be stressed: first, the 'guests' of the previously dominant philanthropic discourses (Arapoglou, 2004) have turned into 'beneficiaries', implying a change in the conditions of care provision; second, logics of activation and self-responsibilization materialize in certain practices along with the provided care (Bourlessas, 2018).

One final particularity to these formal spaces of care reflects, and materializes at the individual level, the neoliberalizing mentality of the welfare state, as the conclusions will suggest. The pivotal to caring practices 'body work' between the object body (of the carerecipient) and subject person (of the care-giver) (Twigg et al., 2011) becomes a personal body work: of the homeless subjects themselves on their own bodies. The usual physical proximity between care-recipients and care-givers (Vaittinen, 2015) is remarkably limited: staff members and volunteers are present principally to provide objects of care, such as soaps and towels, to regulate the infrastructure and to ensure that rules are respected, rather than to care for clients in viscerally involving manners. Care-givers remain distant, care-recipients untouched. Therefore, the 'objects and subjects engaged in the construction and transformation of caring relations and spaces of care' (Hanrahan \& Smith, 2018, p. 1) become inseparable in a mutual making; in these spaces, it is homeless people themselves (subjects) who take care of their own bodies (objects) utilizing the provided infrastructure. The care for one's own body is an individual work. The following subsection introduces 'stigma dialectic' as a useful theoretical framework to locate empirically the personal body work and thus comprehend the spatial making of homeless bodies.

\section{'Stigma dialectic': from spaces (of care) to (homeless) bodies and back}

In his book Stigma: Notes on the Management of Spoiled Identity, Goffman (1963) pursues a constructionist approach to suggest that social stigma is neither pre-existent nor static but, instead, constructed through dynamic relationships, between the stigmatized and the non-stigmatized, the 'normal'. Remember Élsa in the introduction: her body felt stigmatized dialectically, next to mine and the other patrons' non-homeless bodies. It is in what Goffman called 'mixed contacts' that the 'stigmatized' and the 'normal' dynamically relate to one another re-producing hence the stigma; for 'The normal and the stigmatised are not persons but rather perspectives' (ibid., p. 138).

The homeless stigma is particularly strong: 'No matter how multiple and fluid [homeless] identities may be, it is their "homeless" attribute which is seen as the ultimate "self" by others' (McCarthy, 2013, p. 51). Although often marginal, Goffman's ideas have not been absent in homelessness research (see Lancione, 2014; McCarthy, 2013; Parsell, 2011; Rayburn \& Guittar, 2013). A more complete engagement with his interactionist approach is provided by R. J. Smith (2011) and Smith and Hall (2017), who analyze the complexities of stigmatic 
identities in interactions between outreach workers and homeless people in urban settings. Hereby I suggest an extended, spatial understanding so as to effectively re-place the previously criticized 'discursive homeless body'. In a series of Takahashi $(1996,1997)$ ) and Takahashi et al. (2002), have elaborated on the relationship between homeless stigma and space, arguing that stigmatization is not only embodied (by homeless people) but also emplaced (in certain sites) (Takahashi, 1997). Nevertheless, and bridging to the above discussed theoretical constructions of the homeless body, in suggesting her 'continuum of stigma', Takahashi (1996) ignores an essential stigmatizing element that makes homeless people 'out of place' in urban space: dirt. It is this body-space stigmatic relationship, with a special attention to the abstract notion of 'dirt', that I would like to bring forward in relation to Athens' spaces of care.

To this end, I suggest revisiting Goffman's thesis focusing on a specific geographical dimension. Goffman identifies three spatial types that matter to stigma: 'forbidden or out-ofbounds places', inaccessible to the stigmatized; 'civil places', partially accepting the stigmatized yet treating them suspiciously or painfully; and 'back places'. Inside back places the stigmatized persons 'stand exposed and [do not need] to conceal their stigma, nor be overly concerned with cooperatively trying to disattend it' (Goffman, 1963, p. 81). Put differently, the stigma is not hidden but instead released in places ready to tolerate it, accept it, correspond to it, eventually to work the stigma. The night shelter, day centre and hostels are the back places for homeless people in Athens: drawn back from 'normal' society and its spatialities, this is where the - now hidden - homeless stigma is located appropriately, becoming often a prerequisite to access these facilities (see Johnsen et al., 2005; Takahashi et al., 2002). Again, remember Élsa: most probably her body would not have felt (so) inappropriate at the night shelter where she sleeps; yet it did feel so dialectically to the 'normal' cafeteria.

What is the role of these back places in relation to dirt as ingredient of the homeless stigma though? Mary Douglas has shown how social ideas about dirt are not simply about hygiene but rather about order; dirt is dirt as long as it performs 'contraventions of [what is perceived as] order' (Douglas, 1966/2001, p. 36). In a more explicit geographic account, Cresswell (1996) describes dirt's centrality to discourses and practices that render a matter (be it an action, a subject, a group of subjects) 'out of place'; dirt has the capacity to transgress '"commonsense" geographical orderings' (1996, p. 82). If we consider the city as such a geographical ordering, the constructed discursively as dirty, stigmatized homeless bodies transgress this ordering and thus become 'matter out of place' in urban space. Yet, as elements of urban space, spaces of care are integral parts of the overall geographical ordering, which dictates what is 'in place' and what is 'out of place', and where. If '[the] meaning of dirt is dependent on its location' (Cresswell, 1996, p. 38), it is then inside spaces of care as back spaces where the homeless dirt is found 'in its place'.

This in-placeness is reinforced by the fact that back spaces render homeless bodies and their stigma invisible in public space, at least temporarily, by internalizing specific practices, e.g. sleeping and washing oneself, which inscribe a 'visual stigma' upon public space (Speer, 2018). Furthermore, it also contributes to the working of the stigma as it is inside spaces of care as back places where the Goffmanian mixed contacts happen: between the 'stigmatized' homeless (as care-recipients) and the 'normal' staff and volunteers (as caregivers). A wider interpretation of mixed contacts can be suggested though, one that emphasizes the bodies-spaces dialectic: The homeless people's mere placement in these spaces is in itself a meaningful mixed contact as homeless bodies are immersed in 
material, discursive and practized environments that 'normal' society has created for the 'stigmatized'. This placement per se is a mixed contact between bodies and spaces with homeless bodies being 'folded' within these environments (Hetherington, 1997) in a repetitive triple folding-in: body-stigma-place. Homeless stigma embodied, homeless stigma emplaced, to recall Takahashi (1997) - infinitely.

Like so, the interpersonal interactionist approaches on homeless stigmatisation (R. J. Smith, 2011; Smith \& Hall, 2017) can be advanced towards an explicitly spatial fashion, one that embraces spatialities other than the street, namely those of formal care provision, and that attends to the therein discourses, materialities and practices. Analyzing the reciprocal relations between homeless bodies and spaces of care through the stigma dialectic unveils the material effects of homeless stigma and emphasizes the responsive agency of homeless subjects through their personal body work. Before their re-placement in these spaces, it is necessary to replace the homeless body's lost, plural materiality, which homeless subjectivities are made through.

\section{Becoming homeless, becoming anewbody}

Once unsheltered, one's somatic materiality undergoes significant changes. Unprecedented odours, marks and discharges on the skin remake the subject's body. Andréas is a 66-yearold Greek man and vendour of Athens' street paper, who has lived for twenty-seven months in his car after he lost all his property: 'For the first time I developed blisters, pimples with pus on my skin ...', he explained about his first days without shelter. Besides visible signs, the skin might give off undesired odours. For Yánnis, a Greek 60-year-old male resident of a central hostel, the inability to wash himself while sleeping rough and the persistent odours inevitably given off by his body provoked a novel, uncomfortable sense of his own self:

I don't know if you ever approached [homeless] people who ... (pointing at his nose) [stink] [...] Up to two days [without having showered] it is acceptable, armpits start smelling, but on the third and fourth day you start getting soaked in sweat and it's ... a bit ... unpleasant. Mostly for your own self!

Smell changes one's relation with their own body, marking the self through the body. Once corporeal odours have changed, they may remain present on oneself despite any regular access to care infrastructure later in homeless life. Andréas explained:

Even now that I shower two or three times per week, I feel my body smelly ... Most of the times it's just in my mind. [...] Like when you go to the pissoir and flick your [penis] and always leaves something... This smell is as if I have it from [when I was sleeping rough], as if I am still carrying it on myself.

Feelings of a persistent smell were shared amongst research participants who could nevertheless shower regularly at the day centre, night shelter or hostel. 'Body changes change the self' (Synnott, 1993/2002, p. 2); like drops of urine that may remain on one's body after a visit at the pissoir, blisters and especially odours may mark homeless bodies in such a material way that the self is changed forever. For 'homelessness even when distanced, remains felt, remains embodied' (Jolley, 2020, p. 7, original emphasis). The homeless subject is then made not as anybody but rather as anewbody: a new material self. 


\section{Thick skins}

At the age of 58, Hamza from Pakistan sleeps at the night shelter after the small company he was working for closed down and he could not afford his rent: 'My skin has to become thicker now. Not only for the cold, for everything'. As for all night shelter users, he is forced to spend all day long on the streets. Especially in hard weather conditions, the exposed bodies necessitate conscious material adaptations. However, one's novel, thick skin does not only serve to tolerate low temperatures, as Hamza stated metaphorically, but, rather, signifies a broader somatic change. A thick homeless skin is a thick homeless body as the shaping of 'physical selves' is inherent to the making of homeless subjects that have to render their bodies materially resilient to survive street life (Higate, 2000; also BRE, 2007). Not knowing where to eat during the first days in the streets, demands difficult corporeal adaptations that transform the self. Minás, a Greek 60-year-old man sleeping in an NGOrun hostel, remembers those days in Athens' spaces of care: 'Hunger. It has happened that I stayed for five days with no food. I would then find a fountain and drink lots of water. To bloat myself with water. In order not to feel the hunger'.

Being skeptical regarding the provided food, and thus deciding to not eat, becomes a personal physical exercise that trains the body accordingly and fosters material resilience. Tolerating hunger is a physical achievement that is often acknowledged proudly: 'not everyone's body can do this!', Minás enthusiastically added. As the already vulnerable homeless body becomes even more vulnerable due to a temporary illness, one can protect themselves by not ingesting anything, especially when the quality of the soup kitchen's food is not decent. Such practices of material adjustment stress how homeless bodies 'are vulnerable to transformation through action by their owners [aiming to develop] particular aspects of physical "capital"' (Higate, 2000, p. 100), which not only helps the homeless in everyday survival but also materially marks the selves as homeless.

\section{Body-maps}

Besides an amplified bodily boundary for the homeless (Kawash, 1998), the skin is also a personal surface, or 'visage' of signs (Moran, 2012), which performs meanings to the outside (Colls \& Fannin, 2013). For some research participants, a serious accident has been a life cornerstone that marked, both visibly and symbolically, the beginning of their homeless lives and subjectivities. Visible traces of accidents and/or surgical operations on the skin become parts of one's self shaping personal 'body-maps' that the homeless inevitably carry with them, identify themselves with, and narrate. If '[the] body is told, and acted out, through the stories that are folded into it' (Nast \& Pile, 1998, p. 9), it is through the skin as body-map that these stories are folded outwards in spaces of care.

'You cannot see them from where you stand but I still have scars from the stitches [on my head]. They still exist'. Agathí, a 69-year old Greek woman and night shelter user, could spend hours explaining how her body has changed, both inside and outside, after a serious accident that led her to homelessness: 'My leg is sewn together. If you notice, my arms too are sewn together'. Showing with her finger:

From here to here. Till here, if you put them under warm water, you see [the scars] clearly. Till here, see it? [...] On my head I had twenty-six stiches from here to here. This scar is touchable, like a bump. 
She then insisted that I touched her scars by slowly navigating my hand over her arms and head: 'Right here is the gap! From here to here it's all a gap. Do like this, and it's right here!'. Given the role of memories to performing (more-than-)homeless identities (Jolley, 2020), the skin with whatever lies beneath, often becomes the personal site for these memories to be articulated. Agathís body-map does also something more though: it proves materially that her homelessness is not due to personal culpability, as a widespread discourse has it (cf. Takahashi, 1996) and as the neoliberal welfare restructuring implies, but due to an accident and that which followed thereafter. Like this, she performs her homeless self to me, the non-homeless; her skin, visible and tangible, is the evidence of her story.

\section{Practices of cleanliness: making stigmatized homeless bodies 'in place'}

In Athens' spaces of care, specific practices during mixed contacts reinforce the perceptions of dirt associated with homeless bodies. Exemplary is the use of gloves by the personnel and volunteers in order to have physical contact with homeless people and their possessions. 'You (a staff member) go to the toilet, you clean your shit without using gloves ... Am I worse than shit?! You use gloves [to touch us]? Do you treat us (shelter users) like this?' Rahim, a 46-year-old Iranian man at the night shelter, burst out. White plastic gloves are often used even when clean clothes are taken out from the dryer, or when a mug is returned by the homeless person who used it. The gloves that mediate physical contacts between the staff and volunteers, on the one side, and the shelter users and their stuff, on the other, stigmatize the homeless bodies as dirty. In these mixed contacts wrapped in white latex, homeless subjects mobilize their agency to negotiate stigma. Corporeal practices of cleanliness oppose those that materialize the stigma of dirt, repositioning homeless subjects closer to the 'normal', at least temporarily. In this dirt-cleanliness interplay, the body becomes the individual site for embodying, sensing and negotiating stigma through a personal body work staged before the non-stigmatized.

'A clean homeless just came out, yeah!', a man's voice was heard from the bathrooms one evening at the night shelter, provoking laughter to those around. The conscious sarcastic contradiction of putting the words 'clean' and 'homeless' one next to the other illustrates that when homeless bodies are found 'in place', namely in spaces of care, they can be remade as clean again, repelling thus their stigma. Being the terrain for mixed contacts, Athens' spaces of care is where the stigma of dirt can be negotiated through corporeal performances of cleanliness, such as cleaning the hostel's kitchen:

I asked for vinegar to clean. Then the hostel's psychologist came and said 'bravo, the original cleaning!'. I was cleaning the tables upside down, the sink was shining, everybody froze! [...] And then [the staff] said [to the other residents] 'guys, you have to clean as [he] does' [...] [The staff] were happy. And I liked that thing!

For Minás, as for many others, cleanliness is the preeminent bodily way to perform normality at the hostel especially when 'normal' people, such as employees and volunteers, are present. Such mixed contacts, together with the possibilities for practices of cleanliness they offer, highlight how the creation of homeless selves through their agency relates both to (stigmatized) selves as well as to (non-stigmatized) others (Jolley, 2020). 
Furthermore, when these practices are invested with knowledge, the performance of normality is even more successful. 'I asked for vinegar to clean'; Minás did not use any cleaning product disposable at the hostel but asked for vinegar as he knew its natural sanitary effects. Practices of cleanliness are pursued also because care recipients know that this is an effective way to prove their deservedness and guarantee access to the spaces of care. Hamza has been reassured by the shelter's head that his bed there is 'secured' as he is 'one of the cleanest homeless'. In spaces of care of limited resources, and in a local context of increasing poverty and homelessness, clean homeless people ought not to worry; the care they receive is deserved, thus secured.

Conscious about this, Hamza uses cleanliness tactically to distinguish himself from other shelter users: 'You cannot personalize your bed because it's not your own [...] All you can do is keep it clean, cleaner than the others'. Similarly, cleaning his own bodily residues after having trimmed his beard above the sink, Rahim's stigmatized homeless body is performed as clean, thus 'normal' in front of the volunteer:

I took tissues and cleaned the sink. [...] When I finished and there wasn't even one hair, [the volunteer] said: 'I really like it so much! This is what makes you different from others. You could have just opened the water and let it flush down. But you chose another thing, you cleaned it putting [the hairs] where they should be (in the trash bin). This is something special you do, this is not normal'. I told her 'this is normal, what I am doing has to be normal. If [another person] is not doing this, that's abnormal'.

In its explicit reference to normality, this mixed contact exemplifies the importance of bodily practices of cleanliness in negotiating the stigma of dirt and moving closer to a perceived normality. However, if the geographical classifications that dictate what is 'in place' or 'out of place' relate with social values and moralities (Cresswell, 1996), then these practices enabled within spaces of care - therefore 'in place' according to the general geographical ordering - enact also a parallel, social ordering. Found geographically 'in place', homeless subjects utilize their bodies in order to become socially 'in place'. Rahim's practice of carefully cleaning the sink is one of social ordering; precisely of the volunteer's social ordering, of the 'normal', as her 'cherished classifications' (Douglas, 1966/2001, p. 37) were not threatened. Similarly, Minás' practice of cleaning the kitchen (with vinegar) took place at the hostel according to the ordering of the psychologist present.

What is at play then is an overlapping of geographical and social orderings aiming at a respective twofold in-placeness for homeless subjects. To secure their position in the geographical ordering, namely in spaces of care, homeless people must achieve also a social ordering. Cleanliness is central to this: for instance, to get subscribed at the day centre, one must declare their need for showers and not, for instance, for the library or the food; and at the night shelter, showering on a daily basis is an 'unwritten rule', an unofficial requirement for securing one's position there, and a disciplining technique in order to keep homeless people 'active' and 'responsible for themselves', according to the head. The corporeal practising of cleanliness in spaces of care proves the homeless subjects' will for 'rehabilitation' and 'reintegration' - principle purposes of the functioning of these spaces - according to middle-class standards and normalization logics (Arapoglou \& Gounis, 2017; Veness, 1994). Through the practical routinisation of cleanliness in relation to the non-stigmatized staff and volunteers, homeless people achieve 
social ordering through their own bodies: they (prove that they) follow rules, achieve visceral discipline, and are positioned closer to the 'normal' by taking distance from the stigmatized 'dirty homeless', the latter understood as disordered, undisciplined, abnormal - however proximate.

\section{Close to other homeless bodies: performing out-of-placeness while 'in place'}

The productive (body) work of the stigma dialectic does not cease when homeless bodies are 'in place' inside spaces of care; rather, the dual, both geographical and social, inplaceness is in a paradoxical interplay with an intended out-of-placeness. For if homeless bodies are carriers of dirt for mainstream society, so they can be for homeless subjects themselves: 'This is where pus is mustered', a homeless man once told me about Athens' spaces of care; he would consciously avoid therein involvement and seek for alternatives to meet his needs. The perpetual productivity of the stigma dialectic rests in that, located in these spaces, the individual homeless body meets other homeless bodies. Precisely, with other bodies being important to perceptions of dirt (Isaksen, 2002), the clean homeless body meets dirty homeless bodies. 'You see the others ... being very dirty ... and you have to be one meter away from them! Very dirty ... Very difficult', Stéfanos, a 69-year-old Greek man who now lives at the municipal hostel, said of the night shelter where he used to sleep before and where we met for the first time. Together with the mixed contacts between the 'normal' and the 'stigmatized', contacts between the 'stigmatized' and the other 'stigmatized' are productive of the homeless stigma, in visceral manners.

Although 'in place', homeless subjects respond to the inevitable spatial proximity by marking their own bodies as distant from other homeless bodies, which provoke aversion. This aversion relates to bodily residues. The 'pus' used metaphorically by that man materializes: carried by specific bodies, found in specific spaces. 'Maintaining the purity of the self [is] a never-ending battle against residues' (Sibley, 1995, p. 8). The bathrooms are the sites where such battles - in the form of personal body work - take place. They are the par excellence spaces of care inside spaces of care, where the so much desired comfort, care and cleanliness is practiced. Cutting nails, combing hair, defecating, shaving face and/or body parts, cutting hair, urinating, sometimes masturbating, are practices that saturate bathrooms and release residues, such as feces, hairs, nails, urine, blood. Any contact with such materialities threatens one's purity by crossing personal bodily boundaries. At the night shelter, razors are kept in plastic bags with the owners' bed numbers on them. 'Who is the owner of fucking razor 29?! [...] It belongs to a homeless, it can be contaminated!', Rahim came out of the bathroom and shouted at me panic-stricken. He had mistakenly used somebody else's razor. While the aversion towards corporeal residues of other bodies is common (Longhurst, 2001), inside these bathrooms residues become even more threatening because they originate from specific bodies. They are residues not of any bodies but, instead, of homeless bodies - residues of residual bodies. Mixing razors threatened the purity of Rahim's body and self.

Perceptions of both these bodies and spaces as dirty and residual intersect with, and are reinforced by, perceptions of the wider area of Athens, highlighting the links between spaces of care and their urban settings (cf. DeVerteuil et al., 2019; Milligan \& Wiles, 2010). Many research participants expressed their aversion describing the area as grey, dark, a pothole where foreigners, 'blacks' and drug users live - saturated with other 'dirty' 
bodies. Minás said about the hostel's location: 'Here I am scared. A lot of dirt. [...] I walk across Stadíou street ... dis-gust-ing. Then [other] streets, dis-gust-ing! [...] Full of dirty people. [...] The city centre stinks'. When achieved, the so desired in-placeness of homeless bodies in spaces of care is in a paradoxical interplay with an out-of-placeness, which is another form of distancing implied in the making of more-than-homeless selves (Jolley, 2020). Yet, fought for through a constant personal body work, it is mostly a practical, rather than a narrative, distancing; from bodily residues, from residual bodies, from residual spaces - from whatever can threaten the social ordering within the geographical ordering. Conducted 'in place', body work aims infinitely at making the homeless subjects 'out of place'; for, paradoxically, the very geographical in-placeness threatens constantly the social in-placeness. The personal body work keeps the homeless subjects constantly busy.

\section{Conclusions: personal body work, homeless subjectivities and the incorporation of a neoliberal ethic of care}

Informed by literatures on geographies of care, visceral geographies and performative approaches to homeless geographies, this article has attempted a conceptual and spatial re-placement of 'the homeless body'. First, 'the discursive homeless body' has been replaced as material and pluralized 'homeless bodies' so as to stress the corporeal making of subjectivities as homeless. Then, the same bodies have been replaced in Athens' formal spaces of care, in a context of fiscal austerity and neoliberal welfare restructuring. These spaces and the therein homeless bodies are in reciprocal making through a stigma dialectic; the researched hostels, day centre and night shelter are the city's 'back places' where the homeless stigma of 'dirt' is simultaneously emplaced and embodied - where 'dirt' materializes spatially and bodily. Like this, this article has questioned not only where care takes place (Milligan \& Wiles, 2010) but also how it is practiced, especially when specific - and specifically stigmatized - bodies are involved. For the spatial and temporal possibilities 'through which ["the homeless"] create openings to become more-than-homeless' (Jolley, 2020, p. 11) are situated possibilities: enabled yet at the same time restricted by the very spaces they are situated in.

The personal body work, namely the homeless subjects' individual caring for their own bodies is such a situated possibility. Inside formal spaces of care as stigmatic back places, the stigmatized 'dirty' homeless bodies follow a geographical ordering in relation to the overall urban space - they are found spatially 'in place'. Then, the personal body work performs, through practices of cleanliness, a second, social ordering for homeless bodies in relation to the non-stigmatized staff and volunteers they are made socially 'in place'. At the same time though, surrounded by other homeless bodies, equally 'in place' both geographically and socially, yet still considered as dirty, the personal body work aims also at distancing oneself from 'the homeless'; a generalized, homogeneous, stigmatized category, far away from 'the normal'. The embodiment and emplacement of the homeless stigma, though, restricts the distancing and, by restricting it, renders it an infinite and paradoxical bodily effort for homeless subjects: to become 'out of place' while 'in place'. 
By focusing on stigma and its bodies-spaces dialectic, this article has not intended to ignore or simplify the multiple and complex ambivalences of the care and voluntary sector (DeVerteuil et al., 2019; also Cloke et al., 2010). At the same time that the inplaceness/out-of-placeness interplay plays out constantly inside spaces of care keeping the homeless subjects busy, care workers and homeless clients are involved in mutual relations of trust, hope, understanding and affect, while staff members and volunteers might sometimes exceed the limits of their formal roles to care for homeless people in viscerally involving manners. In this final reflection, I argue that the personal body work is exemplary to these ambivalences; for it highlights that care itself can be ambivalent. Performed through spaces and practices that, however indisputably essential to homeless lives, crystallize certain mentalities of an ongoing welfare restructuring, care is more than simply care; rather, it reflects, and materializes, an emerging formal 'ethic of care' (Tronto, 1993) through an institutional poverty management that gets spatialized in central Athens. To reflect upon this 'ethic of care', it is necessary to understand how the personal body work is involved in the visceral subjectification of homeless people as carerecipients. This subjectification works on two interrelated levels.

At a first level, aligned with local discourses and practices of 'activation' enabled by specific spaces of care (Bourlessas, 2018), the personal body work is the par excellence way to incorporate this activation, advancing principles of self-responsibilization (Whiteford, 2010). By remaining 'active' through the constant in-placeness/out-of-placeness interplay, the homeless subjects do not only become responsible for themselves but additionally perform bodily their deservedness: with the unconditional philanthropic mentality losing ground, the active and responsible beneficiaries deserve the benefits they receive, in the form of care. At a second level, relating to wider contemporary ethics of individual responsibility that demand the self to be resilient in a society insecure by default (Evans \& Reid, 2014), the personal body work shapes homeless subjects according to these ethics. It trains them bodily and practically to become resilient subjects both in an increasingly insecure society and, above all, in an increasingly neoliberalizing local welfare of limited resources, where care becomes conditional and selective.

Eventually, the personal body work is the material evidence that formal spaces of care in Athens, by allowing for certain ethoses to be mapped onto them, do not only 'structure interactions with clients' (DeVerteuil et al., 2019, p. 7), but also structure clients themselves. They structure homeless clients as neoliberal subjects who, constantly busy in their paradoxical body work, incorporate, and reproduce at the individual level, the narrowing down of responsibility for poverty and social precariousness in general. This emergent ethic in Athens' spaces of care prescribes that the way out of homelessness is dependent upon the individual precarious self instead of the overall structure that produces precarity. And it prescribes so spatially, through the ambivalent practizing of care itself, and through the bodies of care-recipients.

\section{Note}

1. All names of research participants are pseudonyms. 


\section{Acknowledgments}

My gratitude goes to all research partners as well as to the staff and volunteers of the researched spaces. I would like to thank the journal's Editor and external Reviewers for their collaboration, and to Myrto Dagkouly-Kyriakoglou and Yannis Kallianos for generously discussing and commenting on earlier versions. The article is dedicated to Josie Jolley (1995-2020). Her deep encouragement is the material holding these lines straight, our exchange overall the proof that distant care remains always care. Josie, this piece is for you. For you cared.

\section{Disclosure statement}

No potential conflict of interest was reported by the author.

\section{ORCID}

Panos Bourlessas (iD http://orcid.org/0000-0003-1679-192X

\section{References}

Arapoglou, V. P. (2004). The governance of homelessness in the European South: Spatial and institutional contexts of philanthropy in Athens. Urban Studies, 41(3), 621-639. https://doi.org/ $10.1080 / 0042098042000178717$

Arapoglou, V. P., \& Gounis, K. (2017). Contested landscapes of poverty and homelessness in Southern Europe. Reflections from Athens. Palgrave Mcmillan.

Atkinson, S. (2011). Scales of care and responsibility: Debating the surgically globalised body. Social \& Cultural Geography, 12(6), 623-637. https://doi.org/10.1080/14649365.2011.601263

Atkinson, S., Lawson, V., \& Wiles, J. (2011). Care of the body: Spaces of practice. Social \& Cultural Geography, 12(6), 563-572. https://doi.org/10.1080/14649365.2011.601238

Bartos, A. E. (2018). The uncomfortable politics of care and conflict: Exploring nontraditional caring agencies. Geoforum, 88, 66-73. https://doi.org/10.1016/j.geoforum

Bartos, A. E. (2019). Introduction: Stretching the boundaries of care. Gender, Place \& Culture, 26(6), 767-777. https://doi.org/10.1080/0966369X.2019.1635999

Bondi, L. (2003). A situated practice for (re)situating selves: Trainee counsellors and the promise of counselling. Environment and Planning A: Economy and Space, 35(5), 853-870. https://doi.org/10. 1068/a35135

Bourlessas, P. (2018). 'These people should not rest': Mobilities and frictions of the homeless geographies in Athens city centre. Mobilities, 13(5), 746-760. https://doi.org/10.1080/17450101. 2018.1464544

Bourlessas, P. (2019). Janus in the viscous field: A reflexive account on researching homelessness through institutionalised spaces of care. Area. https://doi.org/10.1111/area.12592

BRE. (2007). Hard livin': Bare life, autoethnography, and the homeless body. In S. Shukaitis, D. Graeber, \& E. Biddle (Eds.), Constituent imagination. Militant investigations/collective theorization (pp. 223-241). AK Press.

Chorianopoulos, I., \& Tselepi, N. (2017). Austerity urbanism: Rescaling and collaborative governance policies in Athens. European Urban and Regional Studies, 26(1), 80-96. https://doi.org/10.1177/ 0969776417733309

Cloke, P., May, J., \& Johnsen, S. (2008). Performativity and affect in the homeless city. Environment and Planning D: Society and Space, 26(2), 241. https://doi.org/10.1068/d84j

Cloke, P., May, J., \& Johnsen, S. (2010). Swept up lives? Re-envisioning the homeless city. WileyBlackwell.

Colls, R., \& Fannin, M. (2013). Placental surfaces and the geographies of bodily interiors. Environment and Planning A: Economy and Space, 45(5), 1087-1104. https://doi.org/10.1068/a44698 
Conradson, D. (2003). Spaces of care in the city: The place of a community drop-in centre. Social \& Cultural Geography, 4(4), 507-525. https://doi.org/10.1080/1464936032000137939

Cox, R. (2010). Some problems and possibilities of caring. Ethics, Place \& Environment, 13(2), 113-130. https://doi.org/10.1080/13668791003778800

Cox, R. (2013). Gendered spaces of commoditised care. Social \& Cultural Geography, 14(5), 491-499. https://doi.org/10.1080/14649365.2013.813580

Cresswell, T. (1996). In Place/Out of Place: Geography, Ideology, and Transgression. University of Minnesota Press

Daya, S., \& Wilkins, N. (2012). The body, the shelter, and the shebeen: An affective geography of homelessness in South Africa. Cultural Geographies, 20(3), 357-378. https://doi.org/10.1177/ 1474474012469886

DeVerteuil, G., May, J., \& Von Mahs, J. (2009). Complexity not collapse: Recasting the geographies of homelessness in a 'punitive' age. Progress in Human Geography, 33(5), 646-666. https://doi.org/ $10.1177 / 0309132508104995$

DeVerteuil, G., Power, A., \& Trudeau, D. (2019). The relational geographies of the voluntary sector: Disentangling the ballast of strangers. Progress in Human Geography, 44(5), 919-937. https://doi. org/10.1177/0309132519869461

Douglas, M. (2001 [1966]). Purity and danger: An analysis of concepts of pollution and Taboo. Routledge.

Dyck, l., Kontos, P., Angus, J., \& McKeever, P. (2005). The home as a site for long-term care: Meanings and management of bodies and spaces. Health \& Place, 11(2), 173-185. https://doi.org/10.1016/j. healthplace.2004.06.001

Evans, B., \& Reid, J. (2014). Resilient life. The art of living dangerously. Polity Press.

Farrugia, D. (2011). The symbolic burden of homelessness: Towards a theory of youth homelessness as embodied subjectivity. Journal of Sociology, 47(1), 71-87. https://doi.org/10.1177/ 1440783310380989

Gerrard, J., \& Farrugia, D. (2014). The 'lamentable sight' of homelessness and the society of the spectacle. Urban Studies, 52(12), 2219-2233. https://doi.org/10.1177/0042098014542135

Goffman, E. (1963). Stigma: Notes on the management of spoiled identity. Prentice-Hall.

Grosz, E. (1994). Volatile bodies. Toward a corporeal feminism. Indiana University Press.

Hanrahan, K. B. (2018). The spaces in between care: Considerations of connection and disconnection for subjects of care. Area, 52(2), 244-250. https://doi.org/10.1111/area.12486

Hanrahan, K. B., \& Smith, C. E. (2018). Interstices of care: Re-imagining the geographies of care. Area, 52(2), 230-234. https://doi.org/10.1111/area.12502

Hayes-Conroy, J., \& Hayes-Conroy, A. (2010). Visceral geographies: Mattering, relating, and defying. Geography Compass, 4(9), 1273-1283. https://doi.org/10.1111/j.1749-8198.2010.00373.x

Hetherington, K. (1997). In place of geometry: The materiality of place. The Sociological Review, 45 (1_suppl), 183-199. https://doi.org/10.1111/j.1467-954X.1997.tb03461.x

Higate, P. R. (2000). Tough bodies and rough sleeping: Embodying homelessness amongst ex-servicemen. Housing, Theory and Society, 17(3), 97-108. https://doi.org/10.1080/ 14036090051084388

Hillis, K. (2008). Building the Cartesian enlightenment: Los Angeles, homelessness and the public sphere. City, 12(3), 283-302. https://doi.org/10.1080/13604810802480686

Hodgetts, D., Stolte, O., Waimarie Nikora, L., \& Groot, S. (2012). Drifting along or dropping into homelessness: A class analysis of responses to homelessness. Antipode, 44(4), 1209-1226. https:// doi.org/10.1111/j.1467-8330.2011.00977.x

Isaksen, L. W. (2002). Toward a sociology of (gendered) disgust: Images of bodily decay and the social organization of care work. Journal of Family Issues, 23(7), 791-811. https://doi.org/10.1177/ 019251302236595

Johnsen, S., Cloke, P., \& May, J. (2005). Day centres for homeless people: Spaces of care or fear? Social \& Cultural Geography, 6(6), 787-811. https://doi.org/10.1080/14649360500353004

Jolley, J. (2020). Embodying Plurality: Becoming more-than homeless. Transactions of the Institute of British Geographers, 45(3), 635-648. https://doi.org/10.1111/tran.12373 
Kaika, M. (2012). The economic crisis seen from the everyday: Europe's nouveau poor and the global affective implications of a 'local'debt crisis. City, 16(4), 422-430. https://doi.org/10.1080/ 13604813.2012 .696943

Kawash, S. (1998). The homeless body. Public Culture, 10(2), 319-339. https://doi.org/10.1215/ 08992363-10-2-319

Lancione, M. (2014). Assemblages of care and the analysis of public policies on homelessness in Turin, Italy. City, 18(1), 25-40. https://doi.org/10.1080/13604813.2014.868163

Lancione, M. (2016). Racialised dissatisfaction: Homelessness management and the everyday assemblage of difference. Transactions of the Institute of British Geographers, 41(4), 363-375. https://doi. org/10.1111/tran.12133

Lawson, V. (2007). Geographies of care and responsibility. Annals of the Association of American Geographers, 97(1), 1-11. https://doi.org/10.1111/j.1467-8306.2007.00520.x

Longhurst, R. (2001). Bodies: Exploring fluid boundaries. Routledge.

Massumi, B. (2002). Parables for the virtual: Movement, affect, sensation. Duke University Press.

McCarthy, L. (2013). Homelessness and identity: A critical review of the literature and theory. People, Place \& Policy Online, 7(1), 46-58. https://doi.org/10.3351/ppp.0007.0001.0004

Milligan, C. (2003). Location or dis-location? Towards a conceptualization of people and place in the care-giving experience. Social \& Cultural Geography, 4(4), 455-470. https://doi.org/10.1080/ 1464936032000137902

Milligan, C., \& Wiles, J. (2010). Landscapes of care. Progress in Human Geography, 34(6), 736-754. https://doi.org/10.1177/0309132510364556

Moran, D. (2012). Prisoner reintegration and the stigma of prison time inscribed on the body. Punishment \& Society, 14(5), 564-583. https://doi.org/10.1177/1462474512464008

Nast, H., \& Pile, S. (Eds.). (1998). Places through the body. Routledge.

Parsell, C. (2011). Homeless identities: Enacted and ascribed. The British Journal of Sociology, 62(3), 442-461. https://doi.org/10.1111/j.1468-4446.2011.01373.x

Power, A., \& Hall, E. (2018). Placing care in times of austerity. Social \& Cultural Geography, 19(3), 303-313. https://doi.org/10.1080/14649365.2017.1327612

Rayburn, R. L., \& Guittar, N. A. (2013). "This is where you are supposed to be": How homeless individuals cope with stigma. Sociological Spectrum, 33(2), 159-174. https://doi.org/10.1080/ 02732173.2013 .732876

Sibley, D. (1995). Geographies of exclusion. Society and difference in the West. Routledge.

Smith, A. F. (2014). In defense of homelessness. Journal of Value Inquiry, 48(1), 33. https://doi.org/10. 1007/s10790-013-9405-x

Smith, R. J. (2011). Goffman's interaction order at the margins: Stigma, role, and normalization in the outreach encounter. Symbolic Interaction, 34(3), 357-376. https://doi.org/10.1525/si.2011.34.3. 357

Smith, R. J., \& Hall, T. (2017). Everyday territories: Homelessness, outreach work and city space. The British Journal of Sociology, 69(2), 372-390. https://doi.org/10.1111/1468-4446.12280

Speer, J. (2018). Urban makeovers, homeless encampments, and the aesthetics of displacement. Social \& Cultural Geography, 20(4), 575-595. https://doi.org/10.1080/14649365.2018.1509115

Synnott, A. (2002 [1993]). The body social. Symbolism, self and society. Routledge.

Takahashi, L. M. (1996). A decade of understanding homelessness in the USA: From characterization to representation. Progress in Human Geography, 20(3), 291-310. https://doi.org/10.1177/ 030913259602000301

Takahashi, L. M. (1997). The socio-spatial stigmatization of homelessness and HIV/AIDS: Toward an explanation of the NIMBY syndrome. Social Science \& Medicine, 45(6), 903-914. https://doi.org/10. 1016/S0277-9536(96)00432-7

Takahashi, L. M., McElroy, J., \& Rowe, S. (2002). The sociospatial stigmatization of homeless women with children in the phoenix area. Urban Geography, 23(4), 301-322. https://doi.org/10.2747/ 0272-3638.23.4.301

Theodorikakou, O., Alamanou, A., \& Katsadoros, K. (2013). "Neo-homelessness" and the Greek Crisis. European Journal of Homelessness, 7(2), 203-210. https://www.feantsa.org/en/european-journal- 
of-homelessness/2013/12/12/european-journal-of-homelessness-volume-7-issue-2-2013? bcParent $=27$

Toft, A. (2014). Contesting the deviant other: Discursive strategies for the production of homeless subjectivities. Discourse \& Society, 25(6), 783-809. https://doi.org/10.1177/0957926514536839

Tronto, J. C. (1993). Moral boundaries. A political argument for an ethic of care. Routledge.

Turner, B. S. (2008). The body and society: Explorations in social theory. Sage.

Twigg, J., Wolkowitz, C., Cohen, R. L., \& Nettleton, S. (2011). Conceptualising body work in health and social care. Sociology of Health \& IIIness, 33(2), 171-188. https://doi.org/10.1111/j.1467-9566.2010. 01323.x

Urry, J. (1995). Consuming places. Routledge.

Vaittinen, T. (2015). The power of the vulnerable body. International Feminist Journal of Politics, 17(1), 100-118. https://doi.org/10.1080/14616742.2013.876301

Veness, A. R. (1994). Designer shelters as models and makers of home: New responses to homelessness in urban America. Urban Geography, 15(2), 150-167. https://doi.org/10.2747/0272-3638. 15.2.150

Watson, S. (2000). Homelessness revisited: New reflections on old paradigms. Urban Policy and Research, 18(2), 159-170. https://doi.org/10.1080/08111140008727830

Whiteford, M. (2010). Hot tea, dry toast and the responsibilisation of homeless people. Social Policy and Society, 9(2), 193-205. https://doi.org/10.1017/S1474746409990340

Wiles, J. (2011). Reflections on being a recipient of care: Vexing the concept of vulnerability. Social \& Cultural Geography, 12(6), 573-588. https://doi.org/10.1080/14649365.2011.601237

Wright, T. (2000). New urban spaces and cultural representations: Social imaginaries, social-physical space, and homelessness. In R. Hutchison (Ed.), Constructions of urban space (research in urban sociology, volume 5) (pp. 23-57). Emerald Group Publishing.

Zambarloukou, S. (2015). Greece after the crisis: Still a south European welfare model? European Societies, 17(5), 653-673. https://doi.org/10.1080/14616696.2015.1103887 